\title{
Environmental Scanning Practices and CEO's Profile
}

\author{
Afef Znaidi ${ }^{1} \&$ Dorra Gherib ${ }^{2}$ \\ ${ }^{1}$ IHEC, University of Carthage, Tunisia \\ ${ }^{2}$ College of Business, University of Jeddah, KSA \\ Correspondence: Dorra Gherib, College of Business, University of Jeddah, KSA. Email: \\ dorra.gherib@gmail.com
}

Received: March 232019

doi:10.5539/ijbm.v14n6p160
Accepted: April 28, 2019

Online Published: May 21, 2019

\begin{abstract}
The main aim of this research work is to study the influence of the CEO's (Chief Executive Officers) profile on environmental scanning practices (ESP) of industrial groups in Tunisia. Theoretical research has only supported the use of the CEO's profile attributes to embody the concept of individual determinants in our research model. The main objective is to measure the influence of the attributes of the CEO's profile on the company's environmental scanning practices (ESP). The methodology adopted is quantitative, and a questionnaire based survey based was conducted with a sample population, namely, subsidiaries of Tunisian groups. The main results from the exploration of the subsidiary's individual attributes linked to the CEO's profile and the test of the hypotheses show the absence of the influence of the type of the CEO's training and his experience on the groups' subsidiary environmental scanning practices in Tunisia. However, the results have also shown that the CEO's level of education had an influence on all the dimensions of environmental scanning practices, with the exception of information storage methods.
\end{abstract}

Keywords: environmental scanning practices; CEO’s profile, Tunisian groups, quantitative study

\section{Introduction}

Environmental Scanning is seen as an important process of strategic management that relates the manager's perceptions and their actions and allows the organization to adapt to the environment (Hambrick D-C, 1981). Thus, highlighting the role of the chief executive officers (CEO's) in the management process seems essential. Moreover, the environmental scanning is the activity of gaining information about events and relationships in the organization's environment; the knowledge of which would assist management in planning future courses action (Auster \& Choo, 1993). Aguilar (1967) defines environmental scanning as acquiring information about events and relationships in a company's outside environment, the knowledge of which would assist senior management in the task of charting the company's future course of action. Environmental scanning is complementary to but distinct from information gathering activities such as competitor intelligence, competitive intelligence and business intelligence. Environmental scanning includes both looking at information (viewing) and looking for information (searching) (Chapus \& Lesca, 1996).

In our study, we figure out the environmental scanning through its practices, it is necessary to identify the dimensions that make it possible to translate the concept of environmental scanning practices (ESP). In this regard, we specify that the latter were largely addressed as part of a previous research work Znaidi et al., (2018) with the aim of improving the perception of environmental scanning through its practical manifestations at the level of the company. Thus, throughout our work, we will build on the results of this previous study regarding the selected dimensions of ESP following an exploratory qualitative study conducted among CEO's within Tunisian corporate groups. The clarifications around ESP and their field perception enabled us to identify the likely contextual factors that influence these practices in the companies. These are organizational, individual and technological factors. As part of this study, we focus solely on individual factors to answer the "how" and "why" questions related to ESP. Thus, the conceptual model that we will later schematize will be used to verify the potential existence of links between these practices and the individual attributes that characterize the company.

In this research, individual determinants are introduced at the conceptual model level only through the attributes of the CEO's profile. This choice is justified by the dominating influence of the executive manager on the behavior of the other stakeholders of the company, and in particular when it comes to meeting the requirements 
of the environment. Thus, since environmental scanning is part of the strategic information management process and a means of adapting the business to its environment, the role of the manager is considered to be the most significant in explaining differences in company information practices (Chapus et al., 1996; Auster et al.,1993; Pansiri, 2005).The majority of studies investigating environmental scanning activities, as directed by Daft's model, have mainly focused on the information collection step, with some easily measurable variables, such as frequency of scanning, use of different kinds of information sources and scanned environmental sectors, while neglecting other activities, such as needs identification, information processing, organizing, dissemination and utilization (Slavetat \& Roy, 2007). In this sense, Daft and Weick (1984) confirm that the distinction between the companies' informational activity levels is related to the data and the manager's perceptions and cognitive maps that make up the organization's interpretation system. All these findings only support the use of the attributes of the CEO's profile to embody the concept of individual determinants in our research model. This study therefore addresses the following question to: What extent can the attributes of the CEO's profile influence the company's ESP?

The rest of this work is structured in three parts. First, we present the theoretical framework as well as the model and research hypotheses that have been addressed. Then we will describe the methodological choices. Finally, we expose the results of this study before discussing them.

\section{Conceptual Framework and Research Hypotheses}

\subsection{The "ESP" Dimension of Our Model}

The environmental scanning practices (ESP) can be perceived according to three possible designs. The first design is object-oriented. It refers to the field of application of the intelligence, that is to say, changes such as signals, events or trends that are under the company's observation and analysis (Mcgee \& Sawyer, 2003; Dishman et al., 2008). Hence the dimension relates to the type of needed information. The second design is mode-oriented. It involves the use of information sources or networks to learn about the environment. These sources can be formal and informal, internal or external (Choo, 1999; Raymond \& Ramangalahy, 2001; Mcgee \& Sawyer, 2003; Du Toit, 2016). It is the dimension relative to the sources of information used. The third design is organization-based. It translates managerial practices in information management. It relates to the diversity of practices used to manage the collection, analysis and dissemination of information. It also refers to the formalization of these practices (Dishman et al., 2008; Amabile et al., 2011; Amabile \& Guechtouli, 2008; Guechtouli, 2014). This design therefore involves the dimensions relating to methods of collecting, analyzing, disseminating or diffusion and storing information, as well as the dimension relating to the formalization of information management. Thus, the "ESP" dimension is addressed, in this work, through the following seven variables: Type of needed information, information sources used, information collected methods, information analysis methods, information dissemination methods, information storage methods and the formalization of information management variable (Znaidi et al., 2018)

Several studies (Kaish et al., 1991; Julien, 1995; Choo, 1999; Raymond et al., 2001) have attempted to develop typologies of ESP by distinguishing them according to the manager's personal attributes. These works suggest that the cognitive abilities of the managers and their involvement in the field of information systems and information and communication technologies influence the company's informational behavior and more particularly their environmental scanning practices. According to upper echelons theory (Hambrick \& Mason, 1984), CEO's and their personal characteristics strongly influence organizational outcomes (Busenbark et al., 2016; Cross \& Hambrick, 2011 and Herrmann \& Nadkarni, 2014), and this influence is increasing over time (Quigley \& Hambrick, 2015). Furthermore, the process of interpreting information from the external environment is often seen as the affair of the management, and each company develops a process of interpretation that is specific to it according to its own attributes and those of the environment in which it evolves. This is consistent with the theory that suggests that the interpretation of information for the purpose of strategic action is often the business of "top management" (Daft \&Weick, 1984). As noted by (Hambrick ,1981; Carpenter et al., 2004; Pansiri, 2005; Hiebl, 2014 ) the manager's personal attributes reflecting his potential and ability to manage organizational difficulties and cope with opportunities and threats from the environment, are generally translated by relatively objective attributes such as age (Lucas, 1975; Reix, 1994 and Nadeau et al., 1988), education (Raymond et al., 2001), experience (Reix,1984 ; Nadeau et al., 1988 ; Cooper et al., 1995; Chapellier, 1997), and training (Nadeau et al., 1988; Mintzberg, 1988; Julien \& Marchesnay, 1988; Holmes et al, 1991; Julien et al., 1995). Given the interest we have in studying the CEO's profile to explain the company's ESP, we propose to embody the concept of the attributes of the CEO's profile at the level of our research model through three variables: the level of education, training and work experience. 


\subsection{Research Hypotheses}

Some studies (Lesca et al., 2012) show that the manager's mental patterns influence their perception of the information issues. The skills of the individual, often dependent on their level of education, play a very important role in the way they collect information. Moreover, Lee and Tsang (2001) argue that factors such as the manager's experience and academic background can influence his ability to analyze and exploit information. These factors can also affect the manager's ability to anticipate, the quality of the solutions he offers, and the way in which he would inform his colleagues. In line, CEO's ownership (the CEO's not only leads the firm but also owns firm shares) and CEO's education as two characteristics to influence the administrative choices of small and medium-sized firms (see Hiebl et al., 2014 and Lavia López \& Hiebl, 2014). This leads to the following general hypothesis:

\section{H1: The CEO's level of education influences ESP}

Hypothesis H1: can thus be expressed through the following sub-hypothesis:

H1a: The CEO's level of education influences the types of needed information

H1b: The CEO's level of education influences the sources of used information

H1c: The CEO's level of education influences information collected methods

H1d: The CEO's level of education influences information analysis methods

H1e: The CEO's level of education influences information disseminated methods

H1f: The CEO's level of education influences information storage methods

H1g: The CEO's level of education influences the formalization of information management

In the context of ESP, by looking at the targets monitored and inspected by the company, Choo (1999) considers that manager's are able to examine areas other than those related to their specialties. However, the author suggests that the importance and extent of environmental scanning activities are often influenced by the CEO's level of education and the nature of his training.

Information collection and analysis processes often depend on the manager's mental schemes and cognitive abilities, which in turn depend on the curriculum and the nature of the training covered. In the same vein, Lesca (1995) considers that the creation of meaning on the basis of incomplete and scattered information is not the affair of a simple mechanical approximation of information but rather results from the combination of knowledge held by certain users and especially the concerns of the managers. We consider at this level that the CEO's concerns are determined by their areas of competence and consequently by their type of training. Thus, new information that would be perceived as distant from the manager's principal concerns may be rejected by the latter. Some authors associate this risk with a cognitive bias resulting from the manager's own knowledge (Lesca, 1995 and Yadav \& Khazanchi, 1992). The following hypothesis is as follows:

\section{H2: The type of the CEO's training influences ESP}

The sub-hypotheses developed from the general hypothesis $\mathrm{H} 2$ are formulated as follows:

H2a: The type of the CEO's training influences the types of needed information

$\mathrm{H} 2 \mathrm{~b}$ : The type of the CEO's training influences the sources of used information

H2c: The type of CEO's training influences information collected methods

H2d: The type of CEO's training influences information analysis methods

H2e: The type of CEO's training influences information disseminated methods

H2f: The type of CEO's training influences information storage methods

$\mathrm{H} 2 \mathrm{~g}$ : The type of CEO's training influences the formalization of information management

Some authors (Ballaz \& Lesca, 1992; Caron et al., 2003), dealing with the manager's skills, specify that the skills acquired through training and especially through experience are closely linked to the quality of interpretation of business intelligence information. According to Bauer and Cohen (1981) professional experience is a means of developing the manager's knowledge and know-how as well as his representations of the environment around him. Indeed, the manager manages to develop, throughout his career, systems of understanding that allow him to anticipate and cope with the diversity of events in his environment (Quinn et al., 1996). 
In the context of ESP, we consider that the professional experience, translated by the different encountered situations, makes it possible to develop the CEO's perception towards the information present in his environment, the information collected and also towards the sources of information to exploit. Thus, the following hypothesis is expressed as follows:

\section{H3: The CEO's professional experience influences ESP}

By influencing ESP, the CEO's professional experience is supposed to influence all the descriptive variables of these practices, hence the following sub-hypothesis:

The sub-hypotheses developed from the general hypothesis $\mathrm{H} 3$ are formulated as follows:

H3a: The CEO's professional experience influences the types of needed information

H3b: The CEO's professional experience influences the sources of information used

H3c: The CEO's professional experience influences information collected methods

H3d: The CEO's professional experience influences information analysis methods

H3e: The CEO's professional experience influences information disseminated methods

H3f: The CEO's professional experience influences information storage methods

H3g: The CEO's professional experience influences the formalization of information management

Figure 1 shows the conceptual model that we propose to test, in an exploratory way, in order to verify the relevance of the links that can exist between ESP and the attributes of the CEO's profile.

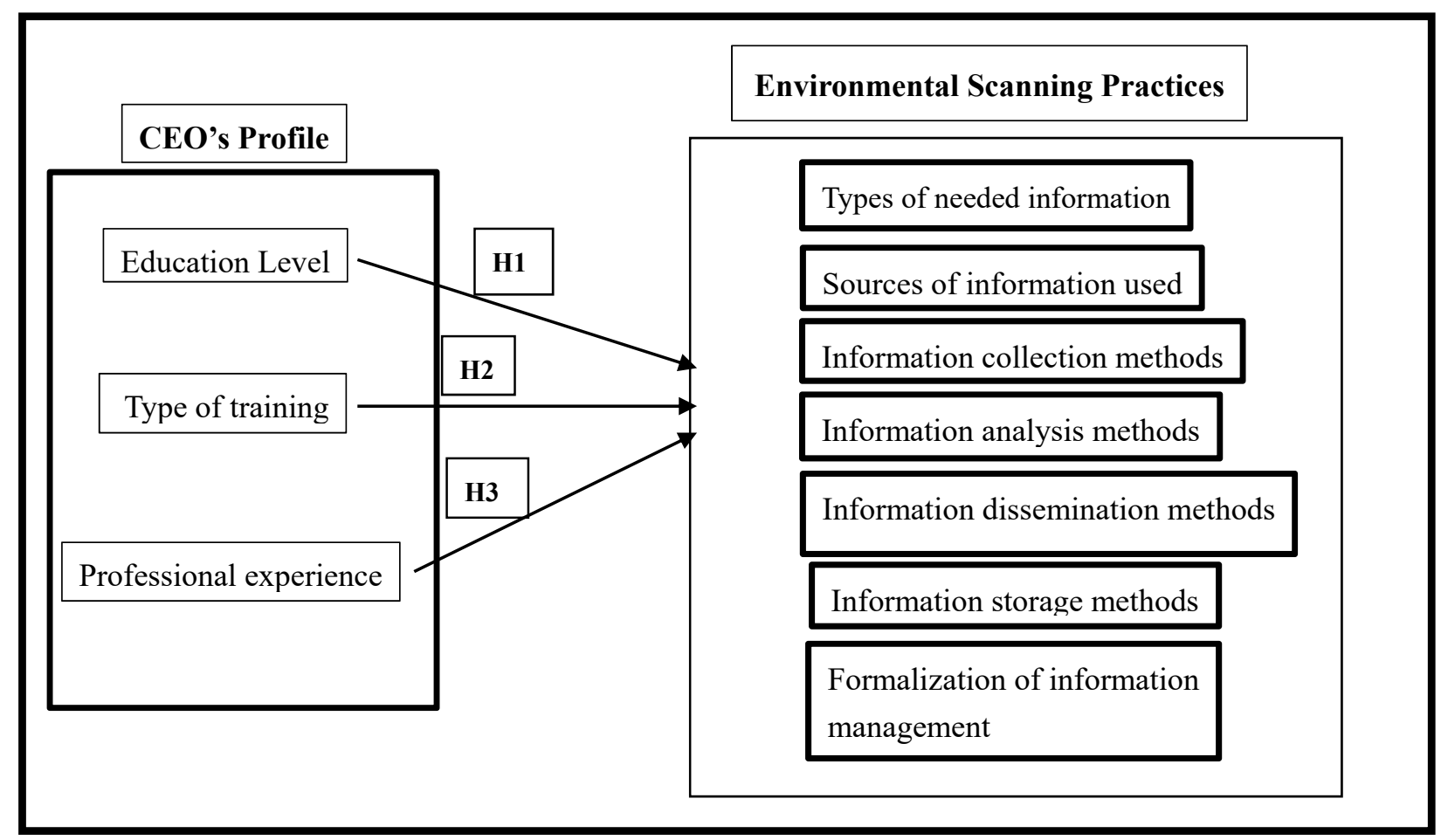

Figure 1. Conceptual model

\section{Research Methodology}

In the context of a quantitative study, a questionnaire based survey was conducted with a sample of subsidiaries of Tunisian companies. The objective of this phase is, on the one hand, to ensure statistical validity of the research model relating to the individual determinants of ESP and, on the other hand, to study and test the possible relationships between the variables (variables related to ESP) and explanatory variables (variables related to the attributes of the CEO's profile). As already mentioned, this quantitative study is a questionnaire 
based survey. The latter, administered to the final sample, is composed of measurement scales specific to each of the variables used in this research. All of these measurement scales were previously pre-tested to ensure their reliability and validity. The next part describes the way in which the measuring instruments used in this research were built and tested. The validation and testing phase of these instruments is discussed in the following section.

Table 1. Synthesis of measurement scales

\begin{tabular}{|c|c|c|}
\hline Model Variable & Item Descriptions & Code \\
\hline $\begin{array}{l}\text { Types of needed information } \\
\text { (Adapted from Raymond et al., 2001) }\end{array}$ & $\begin{array}{l}\text { Financial and human resources information (cost and cost-effectiveness of } \\
\text { technological changes and other investments, recruitment and staff training needs): }\end{array}$ & TNI1 \\
\hline $1=$ never, $2=$ rarely, $3=$ often & Information on innovations (product innovations, processes and equipment) & TNI2 \\
\hline $4=$ Very often, $5=$ always & $\begin{array}{l}\text { Marketing information (identification of potential markets, suppliers and } \\
\text { competitors) }\end{array}$ & TNI3 \\
\hline \multirow{4}{*}{$\begin{array}{l}\text { Sources of used information } \\
\text { (Adapted from Daft et al., 1988) } \\
1=\text { never, } 2=\text { rarely, } 3=\text { often } \\
4=\text { Very often, } 5=\text { always }\end{array}$} & $\begin{array}{l}\text { External sources of impersonal information (publications, newspapers, magazines, } \\
\text { newsletters, books, documents or comments collected in exhibitions, } \\
\text { conference, ...) }\end{array}$ & SIU1 \\
\hline & $\begin{array}{l}\text { Personal external sources of information (contacts with clients, suppliers, bankers, } \\
\text { consultants and contacts at unforeseen meetings...) }\end{array}$ & SIU2 \\
\hline & $\begin{array}{l}\text { Internal sources of impersonal information (documents existing in the company: } \\
\text { activity reports, specific studies, client and supplier files...) }\end{array}$ & SIU3 \\
\hline & $\begin{array}{l}\text { Personal internal sources of information (contacts with employees, subordinates } \\
\text { and anyone belonging to the company...) }\end{array}$ & SIU4 \\
\hline \multirow{3}{*}{$\begin{array}{l}\text { Information collected methods } \\
\qquad \begin{array}{c}1=\text { never, } 2=\text { rarely, } 3=\text { often } \\
4=\text { Very often, } 5=\text { always }\end{array}\end{array}$} & $\begin{array}{l}\text { Collection through contacts (meeting or visit with customers, suppliers, } \\
\text { representatives, sellers...) }\end{array}$ & ICM1 \\
\hline & $\begin{array}{l}\text { Collection through surveys (household surveys, satisfaction surveys, awareness } \\
\text { surveys...) }\end{array}$ & ICM2 \\
\hline & $\begin{array}{l}\text { Collection through the consultation of written or electronic documentation (reading } \\
\text { specialized journals, Internet...) }\end{array}$ & ICM3 \\
\hline \multirow{4}{*}{$\begin{array}{l}\text { Information analysis methods } \\
1=\text { never, } 2=\text { rarely, } 3=\text { often } \\
4=\text { Very often, } 5=\text { always }\end{array}$} & $\begin{array}{l}\text { Cross-referencing analysis (validation of information collected from other } \\
\text { information and sources) }\end{array}$ & IAM1 \\
\hline & Comparative analysis (comparative studies with competition, benchmarking...) & IAM2 \\
\hline & Analysis by simulation (modeling ...) & IAM3 \\
\hline & Analysis by elaboration of scenarios & IDM1 \\
\hline \multirow{4}{*}{$\begin{array}{l}\text { Information disseminated methods } \\
\qquad \begin{array}{c}1=\text { never, } 2=\text { rarely, } 3=\text { often } \\
4=\text { Very often, } 5=\text { always }\end{array}\end{array}$} & $\begin{array}{l}\text { Disseminated through meetings (management meetings, service meetings, quality } \\
\text { circle...) }\end{array}$ & IDM2 \\
\hline & Disseminated by written media (memos, debriefings, mission reports...) & IDM3 \\
\hline & Disseminated by Electronic broadcast (Intranet, internal electronic messaging...) & IDM4 \\
\hline & Disseminated by phone, fax ... & ISM1 \\
\hline Information storage methods & Storage by paper classification. & ISM2 \\
\hline $1=$ never, $2=$ rarely, $3=$ often & Storage by building electronic databases. & ISM3 \\
\hline $4=$ Very often, $5=$ always & Storage by memory of know-how in the form of procedures. & FIM1 \\
\hline $\begin{array}{l}\text { Formalization of information } \\
\text { management }\end{array}$ & $\begin{array}{l}\text { For the company, information management (collection, analysis, dissemination and } \\
\text { storage) is carried out within a dedicated department, department... }\end{array}$ & FMI2 \\
\hline $\begin{array}{l}\text { (Adapted from Salvetat and Le Roy, } \\
\text { 2007) }\end{array}$ & $\begin{array}{l}\text { For the company, information management is subject to written procedures, } \\
\text { methods (internal documents...). }\end{array}$ & FIM3 \\
\hline $1=$ never, $2=$ rarely, $3=$ often & The company allocates a specific budget for information management. & FIM4 \\
\hline $4=$ Very often, $5=$ always & $\begin{array}{l}\text { In the field of information management, the company has a permanent working } \\
\text { group dedicated to this management. }\end{array}$ & FIM5 \\
\hline
\end{tabular}

With regard to measuring instruments purification, the exploratory factor analysis (EFA) and the alpha coefficient do not give information on the homogeneity of a multidimensional measuring instrument. However, given the one-dimensional nature of the measurement scales used in this study, it seems appropriate to retain only these two purification methods without using confirmatory factor analysis (CFA). The methodological framework adopted in this study also provides for a validation phase. This involves the final data collection step followed by two consecutive steps pertaining to the assessment of the reliability and validity of the measuring 
instruments. These last two steps are carried through an EFA and a CFA performed on the basis of the final sample. Indeed, the different variables that operationalize the concept of ESP, like all the other variables of the model, are considered as one-dimensional.

\subsection{Construction and Choice of Measuring Instruments}

This section presents the different measurement tools used in this research. The field pre-survey questionnaire consists of 26 items to measure ESP. The attributes of the CEO's profile were instead measured by nominal variables through open questions and multiple choice questions. The measurement of the different variables was preceded by a presentation of the research framework and its purpose. Finally, a final part was reserved for general information concerning the subsidiary in question, including the nature of its activity, its workforce, its turnover and its system. In line with Royer and Zarlowski's (2007) recommendations concerning the necessity to increase the questionnaire return rate, the latter and in particular the measurement scales were pre-tested. We pre-tested the questionnaire face-to-face with about fifteen branch managers belonging to the final sample of our survey. The final questionnaire version has a total of 24 items.

In the context of our work and in the light of the interviews conducted with branch manager's, we were able to formulate three multiple-choice questions to measure the variables relating to the CEO's level of education, type of training and his professional experience. The corresponding measurement scales are presented in Table (2). In this regard, it should be noted that for the hypotheses testing, we retained only the third question relating to the number of years spent in the current position as a manager of the subsidiary. The other two questions have rather improved our visibility as to the manager's overall experience. For this purpose, the statistical treatments carried out resulted in extracting a median equal to three years of experience. When the number of years is greater than or equal to three, the CEO's experience is considered high and when the number is strictly less than three, the CEO's experience is considered low. The responses are thus treated in a dichotomous manner $(1=$ high experience, 2 = low experience).

Table 2. Measurement Scales of the CEO's Profile

\begin{tabular}{ll}
\hline Education Level & $\begin{array}{l}\text { Please indicate your level of education by checking the correct box: } \\
\text { Bac }<\square \text { Bac }+2 \square \text { Bac }+3 \square \text { Bac }+4 \square \text { Bac }+5>\square\end{array}$ \\
\hline Type of training & Scientific/technical $\square$, Administration $\square$, Legal $\square$ \\
Professionnel experience & $-\quad$ Please indicate the total number of years of experience: ... \\
& - $\quad$ Please indicate the number of years of experience in the current business: ... \\
& - $\quad$ Please indicate the number of years in the current position: ... \\
\hline
\end{tabular}

\subsection{Sample Properties and Date Processing}

The number of CEO's to whom we sent the questionnaire was 283. The number of these CEO's (the CEO's not only leads the firm but also owns firm shares or employees) per group varied according to the total number of subsidiaries belonging to the same group. Initially, the questionnaire was sent to the subsidiary's CEO's electronically and then, in a second time, by combining several means of electronic and telephone reminders. The response rate obtained after the first mailing was 61 questionnaires including 56 usable questionnaires, which represents a relatively high rate. The second mailing of the questionnaire generated 29 usable responses. A telephone reminder to 47 subsidiaries belonging to different groups made it possible to have 21 additional responses. A total of 120 usable questionnaires were collected. The overall response rate was $42.4 \%$. The questionnaires collected were subsequently processed by SPSS specialized software.

In what follows we present the results of the purification of the measurement scales which were subjected to a set of tests making it possible to ensure their reliability and validity. These results are summarized in Tables $(3,4$ and 5). For the validity of the measurement scales, we refer mainly to Carricano and Poujol's (2008) recommendations as follows:

- Bartlett's Specificity Test: it examines the correlation matrix in its entirety and provides the probability of the null hypothesis according to which all correlations are zero.

- KMO Index: it indicates whether the data are consistent together and appropriate for a factor analysis. Thus the KMO values between 0.3 and 0.7 represent acceptable factorial solutions (Table 3 ) 
Table3. KMO and Bartlett test results

\begin{tabular}{|c|c|c|c|c|}
\hline \multirow[t]{2}{*}{ Model Variable } & \multicolumn{4}{|c|}{ KMO and Bartlett test } \\
\hline & $\begin{array}{l}\text { Kaiser-Meyer-O1 } \\
\text { kin. }\end{array}$ & $\begin{array}{l}\text { Khi-deux } \\
\text { approximed }\end{array}$ & Ddl & $\begin{array}{l}\text { Signification } \\
\text { of Bartlett }\end{array}$ \\
\hline Types of needed information & ,714 & 26,675 & 3 & ,000 \\
\hline Sources of information used & 690 & 33,142 & 6 &, 000 \\
\hline Information collection methods & ,722 & 21,703 & 3 &, 000 \\
\hline Information analysis methods & 465 & 24,777 & 6 &, 000 \\
\hline Information dissemination methods & ,706 & 39,330 & 6 &, 000 \\
\hline Information storage methods &, 540 & 38,359 & 3 & ,000 \\
\hline Formalization of information management & 699 & 40,320 & 10 &, 000 \\
\hline
\end{tabular}

We use the percentage variance criterion according to which we observe the cumulative percentages of the variance extracted by the successive factors. The goal is to ensure that one factor accounts for a significant amount of variance. Extraction should be stopped when $60 \%$ of the explained variance is extracted (Table 4).

Table 4. Result of the analysis of the total variance explained

\begin{tabular}{|c|c|c|c|c|c|c|c|}
\hline \multirow[t]{3}{*}{ Model Variable } & & \multicolumn{6}{|c|}{ Total Variance Explained } \\
\hline & & \multirow[b]{2}{*}{ Total } & \multicolumn{2}{|c|}{ Initial Values } & \multicolumn{3}{|c|}{$\begin{array}{c}\text { Extraction total of squares of } \\
\text { selected factors }\end{array}$} \\
\hline & & & $\%$ variance & $\%$ cumuleted & Total & $\begin{array}{l}\% \\
\text { variance }\end{array}$ & $\begin{array}{l}\% \\
\text { cumuleted }\end{array}$ \\
\hline \multirow{4}{*}{ Types of needed information } & TNI1 & 2,520 & 83,997 & 83,997 & 2,520 & 83,997 & 83,997 \\
\hline & TNI2 & ,355 & 11,848 & 95,845 & & & \\
\hline & TNI3 &, 125 & 4,155 & 100,000 & & & \\
\hline & SIU1 & 2,956 & 73,893 & 73,893 & 2,956 & 73,893 & 73,893 \\
\hline \multirow[t]{3}{*}{ Sources of information used } & SIU2 & 654 & 16,347 & 90,240 & & & \\
\hline & SIU3 & ,277 & 6,921 & 97,161 & & & \\
\hline & SIU4 &, 114 & 2,839 & 100,000 & & & \\
\hline \multirow[t]{3}{*}{ Information collection methods } & ICM1 & 2,451 & 81,684 & 81,684 & 2,451 & 81,684 & 81,684 \\
\hline & ICM2 & ,358 & 11,932 & 93,616 & & & \\
\hline & ICM3 &, 192 & 6,384 & 100,000 & & & \\
\hline \multirow[t]{3}{*}{ Information analysis methods } & IAM1 & 2,268 & 75,609 & 75,609 & 2,268 & 75,609 & 75,609 \\
\hline & IAM2 &, 599 & 19,973 & 95,582 & & & \\
\hline & IAM3 &, 133 & 4,418 & 100,000 & & & \\
\hline \multirow[t]{4}{*}{ Information dissemination methods } & IDM1 & 2,832 & 70,799 & 70,799 & 2,832 & 70,799 & 70,799 \\
\hline & IDM2 & ,910 & 22,751 & 93,550 & & & \\
\hline & IDM3 &, 181 & 4,516 & 98,066 & & & \\
\hline & IDM4 &, 077 & 1,934 & 100,000 & & & \\
\hline \multirow[t]{3}{*}{ Information storage methods } & ISM1 & 2,367 & 78,915 & 78,915 & 2,367 & 78,915 & 78,915 \\
\hline & ISM2 & ,603 & 20,087 & 99,002 & & & \\
\hline & ISM3 &, 030 & ,998 & 100,000 & & & \\
\hline \multirow{5}{*}{$\begin{array}{c}\text { Formalization of information } \\
\text { management }\end{array}$} & FIM1 & 3,400 & 67,998 & 67,998 & 3,400 & 67,998 & 67,998 \\
\hline & FMI2 & ,799 & 15,973 & 83,971 & & & \\
\hline & FIM3 & 427 & 8,546 & 92,516 & & & \\
\hline & FIM4 &, 283 & 5,653 & 98,170 & & & \\
\hline & FIM5 &, 092 & 1,830 & 100,000 & & & \\
\hline
\end{tabular}

The Cronbach alpha coefficient assesses the internal coherence of the scale. An acceptable alpha coefficient must be between 0.6 and 0.8 to allow further analysis (Evrard et al., 2003) (see Table 5). 
Table 5 . The results of reliability statistics

\begin{tabular}{lcc}
\hline Model Variable & Reliability statistics & \\
& Alpha Cronbach & Items Numbers \\
\hline Types of needed information &, 898 & 3 \\
Sources of information used &, 877 & 4 \\
Information collection methods &, 885 & 3 \\
Information analysis methods &, 814 & 3 \\
Information dissemination methods &, 852 & 4 \\
Information storage methods &, 858 & 3 \\
Formalization of information management &, 880 & 5 \\
\hline
\end{tabular}

\section{Results}

As mentioned above, to understand the attributes of the CEO's profile within each surveyed subsidiary, we selected the following three variables: (1) level of education, (2) type of training, and (3) professional experience. In what follows, we briefly describe the descriptive statistics that highlight the trends of the selected subsidiaries in terms of the attributes of the CEO's profile.

\subsection{Level of Education}

This variable can be measured in several ways, including asking the respondents an open question to check their level of education.

Table 6. Education level of CEO's

\begin{tabular}{|c|c|c|c|c|c|}
\hline & Bac $<$ & Bac +2 & Bac +3 & Bac +4 & $\mathrm{Bac}+5$ \\
\hline & 1 & 2 & 3 & 4 & 5 \\
\hline Education Level & 0,8 & 10,8 & 16,7 & 40,8 & 30,8 \\
\hline
\end{tabular}

According to the results presented in the table above, it seems that a large majority of the CEO's of the explored subsidiaries have a relatively high level of education, that is to say, a bac (7 years of secondary school education) $+(4$ years of college) for $40.8 \%$ of the subsidiaries and a bac +5 and over for $30.8 \%$ of the subsidiaries. The results reveal that the majority of the interviewed CEO's are likely to promote diversity in the collection of information but also in the choice of methods of analysis, dissemination and storage of the latter.

\subsection{Type of Training}

The exploration of the attributes of the interviewed CEO's reveals that the type of training they had pertains to different fields; including the scientific / technical field, the administration field or the legal field.

Table 7. Type of training of CEO's

\begin{tabular}{lccc}
\hline & Scientific/Technique & Administration & Legal \\
\hline & 1 & 2 & 3 \\
Type of training & 4,2 & 80,0 & 15,8 \\
\hline
\end{tabular}

The results relating to the training nature of the interviewed participants show that they are in the vast majority $(80 \%)$ CEO's. Such training includes areas of commerce, marketing, business, management or finance.

\subsection{Professional Experience}

The professional experience as considered in the context of this study relates to the number of years of experience spent in the current position of CEO's within the studied subsidiary. Note that when the number of years is greater than or equal to three, the CEO's experience is considered high and when the number is strictly less than three, the CEO's experience is considered low. 
Table 8. Professional experience of CEO's

\begin{tabular}{lcc}
\hline & High (1) & Low (2) \\
\hline Professional experience & 85,8 & 14,2 \\
\hline
\end{tabular}

The results relating to the professional experience of the CEO's indicate that a very large majority of these managers $(85.8 \%)$ have a high level of experience, i.e. an experience of at least three years in the position as an executive officer. In this context, and as is the case with the level of education, we consider that a significant experience in terms of the number of years spent at the head of a subsidiary can foster learning in the field of information management and equip the manager with different methods and techniques that help with the information management of his company.

\subsection{Environmental Scanning Practices and CEO's Profile}

The study of the direct effect of individual variables on ESP consists in verifying the existence of linear relationships between the variables related to the CEO's profile, namely, the level of education, the type of training and the work experience, and the variables that operationalize ESP. In the following, we check whether there is a relationship between the CEO's level of education and ESP adopted by the subsidiary.

Table 9. Testing the Relationship between the CEO's Education Level and ESP

\begin{tabular}{|c|c|c|c|c|c|}
\hline & \multicolumn{4}{|c|}{ Level of Education } & \multirow[t]{2}{*}{ Hypothesis H1 } \\
\hline & $\mathrm{F}$ & Ddl & sig. & $\mathrm{R}^{2}$ & \\
\hline Types of needed information & 2.304 & 12.000 & 0.008 & $4.6 \%$ & $\mathrm{H} 1_{\mathrm{a}}:$ accepted \\
\hline Sources of information used & 2.314 & 3.000 & 0.003 & $4.6 \%$ & $\mathrm{H} 1_{\mathrm{b}}$ : accepted \\
\hline Information collection methods & 4.942 & 12.000 & 0.000 & $11.7 \%$ & $\mathrm{H} 1_{\mathrm{c}}:$ accepted \\
\hline Information analysis methods & 2.720 & 3.000 & 0.002 & $6 \%$ & $\mathrm{H} 1_{\mathrm{d}}:$ accepted \\
\hline Information dissemination methods & 2.042 & 16.000 & 0.010 & $16.1 \%$ & $\mathrm{H} 1_{\mathrm{e}}:$ accepted \\
\hline Information storage methods & 1.039 & 12.000 & 0.412 & $1.4 \%$ & $\mathrm{H} 1_{\mathrm{f}}:$ rejected \\
\hline Formalization of information management & 2.434 & 20.000 & 0.001 & $6.6 \%$ & $\mathrm{H} 1_{\mathrm{g}}:$ accepted \\
\hline
\end{tabular}

The results of the study of the relationship between the CEO's level of education and ESP show, according to Table (9), an asymptotic significance of less than 0.05 for the following variables: types of needed information $(0.008)$, sources of information used (0.003), information collection methods (0), information analysis methods (0.002), information dissemination methods (0.010) and formalization of information management (0.001). Thus we reject the null hypothesis of independence and confirm the existence of a relationship between the CEO's level of education and these variables. However, for the information storage methods variable, the results indicate an asymptotic significance of 0.412 , thus greater than 0.05 . As a result we accept the null hypothesis of independence and reject the hypothesis relative to the existence of a relationship between the CEO's level of education and the information storage methods utilized by the subsidiary.

We check in the following if there is a relationship between the CEO's training type and ESP within the subsidiary.

Table 10. Test Influence of the of CEO's training type on ESP

\begin{tabular}{|c|c|c|c|c|c|}
\hline & \multicolumn{4}{|c|}{ Training type } & \multirow[t]{2}{*}{ Hypothesis H2 } \\
\hline & $\mathbf{F}$ & Ddl & sig. & $\mathbf{R}^{2}$ & \\
\hline Types of needed information & 0.492 & 6.000 & 0.814 & $1.5 \%$ & $\mathrm{H} 2_{\mathrm{a}}$ : rejected \\
\hline Sources of used information & 0.673 & 8.000 & 0.714 & $2.8 \%$ & $\mathrm{H} 2_{\mathrm{b}}$ : rejected \\
\hline Information collection methods & 0.530 & 6.000 & 0.785 & $1.3 \%$ & $\mathrm{H} 2_{\mathrm{c}}:$ rejected \\
\hline Information analysis methods & 0.392 & 6.000 & 0.884 & $0.2 \%$ & $\mathrm{H} 2_{\mathrm{d}}$ : rejected \\
\hline Information dissemination methods & 0.793 & 8.000 & 0.609 & $1.2 \%$ & $\mathrm{H} 2_{\mathrm{e}}$ : rejected \\
\hline Information storage methods & 0.818 & 6.000 & 0.557 & $1.1 \%$ & $\mathrm{H} 2_{\mathrm{f}}$ : rejected \\
\hline Formalization of information management & 1.052 & 10.000 & 0.401 & $0.8 \%$ & $\mathrm{H} 2_{\mathrm{g}}$ : rejected \\
\hline
\end{tabular}


From the table above, we note that the asymptotic significance of the links between the CEO's training type and each of ESP variables are all greater than 0.05: type of needed information (0.814), sources of information used (0.714), information collection methods (0.785), information analysis methods (0.884), information dissemination methods (0.609), information storage methods (0.557) and formalization of information management (0.401). Thus, we accept the null hypothesis of independence and as a consequence we reject $\mathrm{H} 2$. That is, we consider that there is no relationship between the CEO's training type and ESP.

In the following we check if there is a relationship between the CEO's professional experience and ESP present in the subsidiary.

Table 11. Test of Influence of the CEO's professional experience on ESP

\begin{tabular}{|c|c|c|c|c|c|}
\hline & \multicolumn{4}{|c|}{ Professional experience } & \multirow[t]{2}{*}{ Hypothesis H3 : } \\
\hline & $\mathbf{F}$ & Ddl & sig. & $\mathbf{R}^{2}$ & \\
\hline Types of needed information & 0525 & 3.000 & 0.666 & $0.00 \%$ & $\mathrm{H} 3_{\mathrm{a}}:$ rejected \\
\hline Sources of information used & 1.450 & 4.000 & 0.222 & $0.02 \%$ & $\mathrm{H} 3_{\mathrm{b}}:$ rejected \\
\hline Information collection methods & 0.569 & 3.000 & 0.637 & $1.2 \%$ & $\mathrm{H} 3_{\mathrm{c}}:$ rejected \\
\hline Information analysis methods & 1.465 & 3.000 & 0.228 & $0.00 \%$ & $\mathrm{H} 3_{\mathrm{d}}:$ rejected \\
\hline Information dissemination methods & 0648 & 4.000 & 0.629 & $1.3 \%$ & $\mathrm{H} 3_{\mathrm{e}}:$ rejected \\
\hline Information storage methods & 0.427 & 3.000 & 0.702 & $0.1 \%$ & $\mathrm{H} 3_{\mathrm{f}}:$ rejected \\
\hline Formalization of information management & 0.718 & 5.000 & 0.612 & $0.00 \%$ & $\mathrm{H} 3_{\mathrm{g}}$ : rejected \\
\hline
\end{tabular}

The results in the table above show that all asymptotic significance is greater than 0.05: type of needed information (0.666), sources of information used (0.222), information collection methods $(0.637)$, information analysis methods $(0.228)$, information dissemination methods (0.629), information storage methods $(0.702)$ and formalization of information management (0.612). Thus, we can accept the null hypothesis of independence and, as a consequence, reject H3, i.e. we should consider that there is no relationship between the CEO's professional experience and ESP.

\section{Discussion and Conclusion}

We were able to empirically confirm the influence of the CEO's education level on the various ESP variables except for information storage methods. The results obtained thus agree with (Hatch, 2000 and Weick 1995; 2001), according to which the environment is a construct that depends on the manager's perception. This perception, generally influenced by the CEO's level of education, will determine the favorite information sources and networks to be used, the information to be collected and the interpretations that result from it. We have assumed that the type of the CEO's training can influence the information needs expressed by the subsidiary and consequently influence the choice of information sources consulted for this purpose. We have also assumed that the CEO's specialty can determine the techniques and methods applied by the subsidiary to collect, analyze, disseminate and store information. However, the results of the hypothesis test reject the existence of links between the type of CEO's training and ESP variables. This empirical finding leads us to question the contribution of certain works (Dubar \& Sainsaulieu, 1988) which consider training as a means of adjusting the manager's abilities to the prerogatives of his environment and influencing his cognitive preferences as well as the order of priority of his concerns. Nevertheless, the existence of a relationship between the type of the CEO's training and the type of information sought by the subsidiary was discredited in this study.

The empirical results for our second hypothesis thus suggest that the CEO's is able to express information needs in domains other than his own and to use information management methods and techniques that are far from the distinctive features of his training.

In this section, we interpret the results obtained concerning the hypothesis test of the link that could exist between the CEO's professional experience and the subsidiary's ESP. In this context, we would like to point out that all the hypotheses formulated for this purpose have been rejected. The empirical results obtained seem to challenge the contributions of some works like Rojot (2005) which explains, based on the principle of limited rationality, that the individual often constructs a simplified model of reality and defines the situations to which he is confronted based on his past experience. Thus, he tends to adopt solutions that have already been used in similar circumstances. From this observation, it seems coherent to consider that depending on the state of the environment and depending on the subsidiary's particular conditions, the CEO's experience will largely determine the expression of the information needs of the latter, the choice of information sources, the methods 
and techniques of collecting, analyzing, disseminating and storing information that he would tend to use. Nevertheless, all these considerations have been refuted based on the results of our fieldwork.

The empirical results related to our third hypothesis also diverge from Ballaz and Lesca (1992) study which shows that in the context of ESP, the collection and the quality of interpretation of the information are closely related to the observer's expertise, skills acquired through training and professional experience. As is the case with the interpretation of the results of the hypothesis test relating to the links that can exist between the level of education and the CEO's training, on the one hand, and the variables reflecting ESP, on the other hand, the possible explanation of the empirical results obtained with respect to the CEO's professional experience would be that despite the dominant role of the subsidiary's manager, information practices are often performed by the other members of the subsidiary. Indeed, the order of priority of the CEO's concerns and the pertaining strategic nature in most cases exploit the results of the subsidiary's information processes, which include the environmental scanning process. Consequently, the skills used in the context of ESP do not necessarily result from the type of the CEO's training or from his professional experience but rather from the collective knowledge and skills that depend on the attributes of the staff profile.

As a conclusion, we can call to mind that the aims of this research paper is to highlight the explanatory power of certain variables related to the specificities of the CEO's profile within the framework of the ESP. The finding that only the effect of the variable relative to the CEO's educational level is confirmed, leads us to reflect on the limits of our work. Thus, it is possible to take into account that the consideration of other variables in the apprehension of the specificities of the CEO's profile could have involved different results. Starting from this limit, some research perspectives are derived. The first one would consist in taking into consideration the apprehension of the CEO's profile, then the variable relating to the CEO's culture which is translated mainly by his beliefs and values. Another possible research perspective would be to reproduce the same study by incorporating new variables in the apprehension of individual specificities that might influence the ESP of the affiliate as well as the staff profile.

\section{References}

Aguilar, F. J. (1967). Scanning the business environment. New York: Macmillan.

Amabile, S., \& Guechtouli M., (2008).Veille et sélection de l'information : intégrer les acteurs dans le développement de filtres informationnels intelligents. Revue Finance, Contrôle, Stratégie, 1(3), 189-215.

Amabile, S., Laghzaoui, S., \& Boudrandi, S. (2011). Pratiques de veille stratégique par les PME exportatrices. Management \& Avenir, 44(4), 15. https://doi.org/10.3917/mav.044.0015

Auster, E., \& Choo, C. W. (1993). Environmental scanning by CEOs in two Canadian industries. Journal of the American Society for Information Science, $44(4), \quad$ 194-203. https://doi.org/10.1002/(sici)1097-4571(199305)44:43.0.co;2-1

Ballaz B. \& Lesca H., (1992). Le processus de veille stratégique : l'examen de quelques questions importantes, Cahier de Recherche du CERAG n $92-05$, Grenoble, Mai.

Bauer, M., \& Cohen, E. (1981). Qui gouverne les groupes industriels? Editions du Seuil, Paris.

Barreau, D. (2000). Information Management for the Intelligent Organization: The Art of Scanning the Environment (2nd ed.). Library \& Information Science Research, 22(3), 343-345. https://doi.org/10.1016/S0740-8188(00)00046-3

Brouard, F., \& Larivet, S. (2007). La veille stratégique, un outil pour améliorer la Gouvernance. Actes Electroniques du Colloque Entrepreneuriat : nouveaux enjeux, nouveaux comportements, ISC, Paris, Juin.

Busenbark, J., Krause. R., Boivie. S, (2016). Toward a Configurational Perspective on the CEO: A Review and Synthesis of the Management Literature. Journal of Management, 42(1) https://doi.org/10.1177/0149206315618448

Caron-Fasan, M., \& Lesca, H. (2003). Implantation d'une veille stratégique (v.s.) pour le management stratégique : Cas d'une PME du secteur bancaire. La Revue Des Sciences De Gestion, Direction Et Gestion, (203), 55-68. doi:10.1051/larsg:2003020 https://doi.org/10.1051/larsg:2003020

Carpenter, M. A., Geletkanycz, M. A., \& Sanders, W. G. (2004). Upper Echelons Research Revisited: Antecedents, Elements, and Consequences of Top Management Team Composition. Journal of Management, 30(6), 749-778. https://doi.org/10.1016/j.jm.2004.06.001

Carricano, F. P. (2008). Analyse de données avec SPSS - Marketing Research (103) Pearson Schweiz AG. 
Retrieved from

https://www.pearson.ch/HigherEducation/PearsonFrance/EAN/9782744072772/Analyse-de-donnees-avec-S PSS

Chapellier. (1997). Profils de dirigeants et données comptables de gestion en PME. Revue Internationale de PME, 10(1), 9-42. https://doi.org/10.7202/1009016ar

Chapus, E., \& Lesca, H. (1996). Implantation d'une veille stratégique en coopération en milieu de PMI. Actes du 11éme Colloque International de Management des Réseaux d'Entreprises CIMRE.

Choo, C. W. (1999). The art of scanning the environment . Bulletin of the American Society for Information Science. Bulletin of the American Society for Information Science, 25(3), 21-24.

Cooper, A. C., Folta, T. B., \& Woo, C. (1995). Entrepreneurial information search. Journal of Business Venturing, 10(2), 107-120. https://doi.org/10.1016/0883-9026(94)00022-M

Crossland, C., J., Zyung, N. J., \& Hambrick, D. C. (2014). CEO career variety: Effects on firm-level strategic and social novelty. Academy of Management Journal, 57, 652-674. https://doi.org/10.5465/amj.2012.0469

Daft, R. L., \& Weick, K. E. (1984). Toward a Model of Organizations as Interpretation Systems. The Academy of Management Review, 9(2), 284. https://doi.org/10.2307/258441

Dishman, P. L., \& Calof, J. L. (2008). Competitive intelligence: A multiphasic precedent to marketing strategy. European Journal of Marketing, 42(7/8), 766-785. https://doi.org/10.1108/03090560810877141

Dubar, C., \& Sainsaulieu, R. (1988). Sociologie de l'organisation et de l'entreprise. Revue Française De Sociologie, 29(3), 528. https://doi.org/10.2307/3321630

Duprez, J., Bauer, M., \& Cohen, E. (1983). Qui gouverne les groupes industriels? Essai sur lexercice du pouvoir du et dans le groupe industriel. Revue Française De Sociologie, 24(2), 345. https://doi.org/10.2307/3321476

Evrard, Y., Pras, B., \& Roux, E. (2003). Market. Etudes et recherches en Marketing (3rd ed.).

Guechtouli, M. (2014). Management des activités de veille stratégique. La Revue Des Sciences De Gestion, 266(2), 23. https://doi.org/10.3917/rsg.266.0023

Hambrick, D. C. (1981). Specialization Of Environmental Scanning Activities Among Upper Level Executives. Journal of Management Studies, 18(3), 299-320. https://doi.org/10.1111/j.1467-6486.1981.tb00104.x

Hatch, M. J. (2000). Théorie des organisations. De l'intérêt de perspectives multiples. Edition De Boeck Université, 18(3), 115-126. https://doi.org/10.1023/A:1026797014603

Herrmann, P., \& Nadkarni, S. (2014). Managing strategic change: The duality of CEO personality. Strategic Management Journal, 35, 1318-1342. https://doi.org/10.1002/smj.2156

Hiebl, M. R. (2013). Upper echelons theory in management accounting and control research. Journal of Management Control, 24(3), 223-240. https://doi.org/10.1007/s00187-013-0183-1

Holmes, S., Kelly, G., \& Cunningham, R. (1991). The Small Firm Information Cycle: A Reappraisal. International Small Business Journal: Researching Entrepreneurship, 9(2), 41-53. https://doi.org/10.1177/026624269100900203

Julien, P. A. (1995). The competitiveness of small and medium enterprises. Retrieved from https://www.sciencedirect.com/science/article/pii/S0883902600000586

Kaish, S., \& Gilad, B. (1991). Characteristics of opportunities search of entrepreneurs versus executives: Sources, interests, general alertness. Journal of Business Venturing, 6(1), 45-61. https://doi.org/10.1016/0883-9026(91)90005-X

Lavia Lopez, O., \& Hiebl, M. R. W. (2014). Management Accounting in Small and Medium sized Enterprises: Current Knowledge and Avenues for Further Research. Journal of Management Accounting Research. https://doi.org/10.2308/jmar-50915

Lesca H., \& Caron, M. L. (1995). Veille stratégique : créer une intelligence collective au sein de l'entreprise. Revue Française de Gestion.

Lesca, N., Caron-Fasan, M., \& Falcy, S. (2012). How managers interpret scanning information. Information \& Management, 49(2), 126-134. https://doi.org/10.1016/j.im.2012.01.004

Lucas, H. C. (1975). Performance and the Use of an Information System. Management Science, 21(8), 908-919. https://doi.org/10.1287/mnsc.21.8.908 
Mcgee, J. E., \& Sawyerr, O. O. (2003). Uncertainty and Information Search Activities: A Study of Owner-Managers of Small High-Technology Manufacturing Firms. Journal of Small Business Management, 41(4), 385-401. https://doi.org/10.1111/1540-627X.00089

Mintzberg, Y., \& Mintzberg, H. (1988). Strategy Making as Craft. Innovation and Management, 167-196. https://doi.org/10.1515/9783110864519-012

Nadeau R., Martel J-J. \& M'zalli B., (1988). L'utilisation des méthodes quantitatives pour la décision de gestion dans les PME québécoises : une étude empirique. Papier de recherche, Université de Laval, Québec.

Pansiri, J. (2005). The influence of managers characteristics and perceptions in strategic alliance practice. Management Decision, 43(9), 1097-1113. https://doi.org/10.1108/00251740510626218

Quigley, T., \& Hambrick, D. (2015). Has the CEO 'effect increased' in recent decades ? A new explanation for the great rise in America attention to corporate leaders. Strategic Management Journal Strat. Mgmt. J., 36, 821-830. https://doi.org/10.1002/smj.2258

Quinn, J. (1998). Managing Professional Intellect: Making the Most of the Best. The Strategic Management of Intellectual Capital, 87-98. https://doi.org/10.1016/B978-0-7506-9850-4.50009-9

Raymond, L., Julien, P., \& Ramangalaby, C. (2001). Technological Scanning by Small Canadian Manufacturers. Journal of Small Business Management, 39(2), 123-138. https://doi.org/10.1111/1540-627X.00012

Reix R., (1984). Quelques facteurs affectant l'utilisation d'informations de caractère comptable. Actes du 5éme Congrès de l'Association Française de Comptabilité, AFC.

Roiron, L., \& Lesca, H. (1996). La veille stratégique dans les entreprises britanniques. La Revue Des Sciences De Gestion, Direction Et Gestion, (162), 23-33. https://doi.org/10.1051/larsg:1996039

Rojot, J. (2005). Théorie des organisations - J. Rojot - 2ème édition - Librairie Eyrolles. Retrieved from https://www.eyrolles.com/Entreprise/Livre/theorie-des-organisations-9782747207409/

Royer, I., \& Zarlowski, P. (2007). Echantillons. In Thiétart \& Coll (Eds.), Méthodes de recherche en management. Dunod, Paris.

Thietart, R., Allard-Poesi, F., Angot, J., Baumard, P., Blanc, A., Cartier, M., \& Zarlowski, P. (2019). Méthodes de recherche en management. Retrieved from https://www.dunod.com/entreprise-economie/methodes-recherche-en-management

Toit, A. D. (2016). Using environmental scanning to collect strategic information: A South African survey. International Journal of Information Management, $\quad 36(1), \quad 16-24$. https://doi.org/10.1016/j.ijinfomgt.2015.08.005

Salvetat, D., \& Roy, F. L. (2007). Compétition et intelligence économique. Revue Française De Gestion, 33(176), 147-162. https://doi.org/10.3166/rfg.176.147-162

Zhang, X., Majid, S., \& Foo, S. (2010). Environmental scanning: An application of information literacy skills at the workplace. Journal of Information Science, 36(6), 719-732. https://doi.org/10.1177/0165551510385644

Vacher B. (1997). La gestion de l'information en entreprises: enquête sur l'oubli, l'étourdie, la ruse et le bricolage organisés. ADBS Editions.

Weick, E. (1995). Sense making in organizations. London, Sage Publications.

Yadav, S. B., \& Khazanchi, D. (1992). Subjective understanding in strategic decision making. Decision Support Systems, 8(1), 55-71. https://doi.org/10.1016/0167-9236(92)90037-P

Znaidi A., Boussoura E., \& Zribi O. (2018). Veille stratégique: du concept à la pratique Cas de groupes d'entreprises tunisiennes. XXVIIe Conférence Internationale de Management Stratégique Retrieved from https://www.strategie-aims.com/events/conferences/29-xxviieme-conference-de-1-aims/communications/51 19-veille-strategique-du-concept-a-la-pratique-cas-de-groupes-dentreprises-tunisiennes/download

\section{Copyrights}

Copyright for this article is retained by the author(s), with first publication rights granted to the journal.

This is an open-access article distributed under the terms and conditions of the Creative Commons Attribution license (http://creativecommons.org/licenses/by/4.0/). 